\title{
PENGARUH BERBAGAI JENIS DAN DOSIS PUPUK KANDANG TERHADAP PERTUMBUHAN DAN HASIL TANAMAN BAWANG MERAH VARIETAS LEMBAH PALU
}

\section{EFFECTS OF VARIOUS TYPES AND DOSES OF MANURE ON GROWTH AND RESULTS OF SHALLOT VARIETY OF PALU VALLEY}

\author{
Idris $^{{ }^{*}}$, Muhammad Basir ${ }^{2}$, Imam Wahyudi ${ }^{2}$ \\ ${ }^{1}$ Mahasiswa Program Studi Ilmu-Ilmu Pertanian, Program Pascasarjana, Universitas Tadulako, \\ Jl. Sukarno Hata, Palu, Indonesia \\ ${ }^{2}$ Program Studi Ilmu-Ilmu Pertanian, Program Pascasarjana, Universitas Tadulako, \\ Jl. Sukarno Hata, Palu, Indonesia
}

\begin{abstract}
ABSTRAK
Penelitian bertujuan untuk menguji pengaruh berbagai jenis pupuk kandang yang dikombinasikan dengan berbagai dosis terhadap pertumbuhan dan hasiltanaman bawang merah varietas Lembah Palu. Penelitian ini didesain dengan menggunakan Rancangan Acak Kelompok (RAK) faktorial. Faktor pertama adalah pupuk kandang dengan tiga jenis perlakuan, yaknipupuk kandang ayam (P1), pupuk kandang kambing (P2), pupuk kandang sapi (P3). Faktor kedua adalah dosis pupuk kandang yang terdiri atas tiga perlakuan, yakni10 $\mathrm{t} \mathrm{ha}^{-1}\left(3,6 \mathrm{~kg}_{\text {petak }}{ }^{-1}\right)(\mathrm{D} 1)$, dosis $20 \mathrm{tha}^{-1}\left(7,2 \mathrm{~kg} \mathrm{petak}^{-1}\right)(\mathrm{D} 2)$, dosis $30 \mathrm{tha}^{-1}$ $\left(10,8 \mathrm{~kg} \mathrm{petak}^{-1}\right)(\mathrm{D} 3)$. Hasil penelitian menunjukkan bahwa kombinasi perlakuan berbagai jenis dan dosis pupuk kandang ayam berinteraksi pada parameter tinggi tanaman umur 35 HST, dimana perlakuan pupuk kandang ayam dengan dosis $30 \mathrm{t} \mathrm{ha}^{-1}$ memberikan hasil lebih baik. Perlakuan tunggal jenis pupuk kandang ayam memberikan hasil lebih baik terhadap tinggi tanaman, berat segar daun, berat kering akar, berat kering daun dan berat segar umbi per rumpun. Perlakuan tunggal dosis pupuk kandang $30 \mathrm{t} \mathrm{ha}^{-1}$ memberikan hasil lebih baik terhadap tinggi tanaman, luas daun, berat segar daun, berat kering daun, berat segar umbi per petak, dan berat segar umbi per hektar.
\end{abstract}

Kata kunci:Pupuk Kandang, Bawang Merah, Pertumbuhan dan Hasil

\section{ABSTRACT}

Research aims to test the effectiveness of various types of manure combined with various doses of application for the growth and result of shallot varieties of Palu Valley. This research was designed using factorial randomized block design. The first factor was manure with three types of treatment, namely chicken manure (P1), got manure (P2), cow manure (P3). The second factor was the dose of manure consisting of three types of treatment, namely $10 \mathrm{tha}^{-1}\left(3,6 \mathrm{~kg} \mathrm{plot}^{-1}\right)(\mathrm{Dl}), 20 \mathrm{tha^{-1 }}\left(7,2 \mathrm{~kg} \mathrm{plot}^{-1}\right)(\mathrm{D} 2)$, $30 \mathrm{t} \mathrm{ha}^{-1}\left(10,8 \mathrm{~kg} \mathrm{plot}^{-1}\right)(\mathrm{D} 3)$. The results show that the combination of various types of treatment and doses of chicken manure interacts on plat height parameters aged 35 days after planting. The treatment of chicken manure with a dose of $30 \mathrm{th} \mathrm{h}^{-1}$ gives better results. The single treatment of chicken manure gave better results for the plant height, weight of leaves, root dry weight, leaf dry weight, number of tubers per clump. Single treatment of manure dosage of $30 \mathrm{th} \mathrm{h}^{-1}$ gave better results on plant height, leaf area, leaf fres weight, leaf dry weight tuber fresh weight per hectare.

Keywords: Manure, Shallot, Growth and Results

\section{Pendahuluan}

Tanaman bawang merah merupakan salah satu komoditas hortikultura unggulan yang sejak lama telah budidayakan oleh petani secara intensif. Komoditas ini juga merupakan sumber pendapatan dan kesempatan kerja yang memberikan kontribusi yang cukup tinggi terhadap perkembangan ekonomi daerah.Usaha budidaya bawang merah telah menyebar hampir disemua provinsi di Indonesia termasuk Sulawesi 


\section{Jurnal Agrotech 8 (2) 40-49}

Tengah, karena memiliki nilai ekonomi yang cukup tinggi.

Tanaman bawang merah lokal Provinsi Sulawesi Tengah, seperti varietas Tinombo, Palasa, dan Lembah Palu terus dikembangkan. Bahkan pengembangan ketiga varietas lokal tersebut tidak hanya berorientasi spesifik pada masing-masing lokasi, akan tetapi ke beberapa daerah kabupaten yang ada di Provinsi Sulawesi Tengah dan di luar Provinsi Sulawesi Tengah.

Bawang merah varietas Lembah Palu merupakan bahan baku industri pengolahan bawang goreng serta telah menjadi "brand lokal" Kota Palu. Salah satu keunikan bawang ini yang membedakan dengan bawang merah lainnyaadalah umbinya mempunyai tekstur yang padat sehingga menghasilkan bawang goreng yang renyah dan gurih serta aroma yang tidak berubah walaupun disimpan lama dalam wadah yang tertutup.Selain itu, ciri bawang merah varietas Lembah Palu berdasarkan morfologi daun adalah daun tegak hingga waktu panen.Ciri tersebut juga terlihat pada bawang merah Tinombo dan Sumenep, perbedaannya adalah daun bawang merah varietas Lembah Palu berwarna hijau agak pucat sedangkan bawang merah Tinombo dan Sumenep berwarna hijau tua.Dilihat dari morfologi umbi, bawang merah varietas Lembah Palu memiliki bentuk umbi silindris seperti pipa, bulat agak memanjang dengan ukuran agak kecil.Ciri-ciri tersebut mirip dengan bawang merah Tinombo dan Sumenep, perbedaannya adalah umbi bawang merah varietas Lembah Palu berwarna lebih pucat daripada bawang Sumenep (Limbongan dan Maskar, 2003).

Produksi bawang merah Sulawesi Tengah tahun 2014 hanya mencapai 6.923,3 ton dari luas panen 1.315 ha dengan produktivitas 5,3 ton/ha (BPS, 2015). Sementara berdasarkan SK Menteri Pertanian No.1843/Kpts/SR.120/4/2011 tentang "Pelepasan Bawang Merah Varietas Lembah Palu sebagai Varietas Unggul" bahwa produktivitasnya dapat mencapai 9,7 ton/ha.

Salah satu komponen dari teknik budidaya yang dapat diperbaiki untuk meningkatkan hasil tanaman bawang merah dapat dilakukan dengan penerapan teknologi pemupukan. Pemberian pupuk sebagai upaya menambah ketersediaan hara didalam tanah sangat perlu diperhatikan.

\footnotetext{
${ }^{*}$ Penulis Korespondensi

E-mail: idris.doank45@yahoo.com

Telp: +62-82291621880
}

e-ISSN : 2621-7236

p-ISSN : 1858-134X

Pemupukan dapat berpengaruh langsung terhadap pertumbuhan tanaman, karena unsur hara merupakan kebutuhan yang esensial bagi tanaman.

Saat ini petani lebih mengenal pupuk anorganik seperti pupuk tunggal (Urea, TSP, dan $\mathrm{KCl}$ ) dan pupuk majemuk (Phonska). Namun tidak disadari bahwa penggunaan pupuk anorganik secara terus-menerus dalam jangka waktu yang lama justru akan menurunkan kualitas tanah. Menurut Parman (2007) bahwa dampak buruk dari penggunaan pupuk anorganik adalah tanah menjadi cepat mengeras, kurang mampu menyimpan air, dan cepat menjadi asam yang pada akhirnya akan menurunkan produktivitas tanaman.

Upaya yang dapat dilakukan untuk mengatasi dampak buruk dari pupuk anorganikadalah penggunaan pupuk organik. Pupuk kandang merupakan salah satu jenis pupuk organik yang banyak digunakan oleh petani, seperti kotoran sapi, kambing dan ayam. Meskipun mengandung kandungan unsur hara yang rendah, pupuk kandang berperan cukup besar dalam memperbaiki sifat fisik, kimia, dan biologis tanah, serta lingkungan. Penggunaan pupuk kandang juga dapat mengurangi pencemaran lingkungan karena bahan-bahan organik tersebut tidak dibuang sembarangan yang dapat mengotori lingkungan terutama pada perairan umum.

Selain itu, menurut Setiawan (1996) bahwa dengan pemberian pupuk kandang pada areal pertanaman, dapat meningkatkan daya serap air tanah serta dapat memberikan lingkungan yang baik untuk perkecambahan biji dan akar tanaman. Lebih lanjut dijelaskan bahwa kandungan unsur hara yang terdapat dalam kotoran ternak yang terpenting adalah kandungan unsur nitrogen $(\mathrm{N})$, mengingat unsur $\mathrm{N}$ dapat merangsang pertumbuhan tanaman secara keseluruhan, fosfor (P) berfungsi untuk merangsang pertumbuhan akar dan kalium (K) berfungsi untuk memperkuat jaringan tanaman sehingga daun, bunga, buah tidak mudah gugur.

Salah satu aspek pemupukan yang berpengaruh terhadap tanggap tanaman adalah penggunaan dosis.Dosis yang tepat (optimum) merupakan kebutuhan pupuk yang sesuai bagi pertumbuhan tanaman.Dosis pupuk kandang dapat berbeda tergantung dari jenis pupuk kandang yang diaplikasikan, sehingga perlu adanya kajian lebih lanjut untuk mengetahui dosis optimum dari berbagai jenis pupuk kandang 


\section{Jurnal agrotech 8 (2) 40-49}

untuk tanaman bawang merah varietas Lembah Palu.

\section{Tujuan Penelitian}

1. Mengetahui pengaruh interaksi berbagai jenis dan dosis pupuk kandang terhadap pertumbuhan dan hasil tanaman bawang merah varietas Lembah Palu

2. Mengetahui pengaruh berbagai jenis pupuk kandang terhadap pertumbuhan dan hasil tanaman bawang merah varietas Lembah Palu

3. Mengetahui pengaruh berbagai dosis pupuk kandang terhadap pertumbuhan dan hasil tanaman bawang merah varietas Lembah Palu

\section{Metode Penelitian}

Penelitian inidilaksanakan di Desa Oloboju Kecamatan Sigi Biromaru Kabupaten Sigi Provinsi Sulawesi Tengahpada bulan September sampai dengan November 2017.

Bahan yangdigunakan pada penelitian ini adalah benih bawang merah varietas Lembah Palu, pupuk kandang ayam,pupuk kandang kambing, pupuk kandang sapi dan air. Alat yang digunakan berupatraktor tangan (handtracktor), cangkul, kored, meteran, timbangan, parang, pisau, gunting, ember, gembor, papan label, kamera dan alat tulis menulis.

Penelitian ini menggunakan Rancangan Acak Kelompok (RAK) pola faktorial dengan pengelompokkan berdasarkan berat umbi. Perlakuan yang dicobakan terdiri atas dua faktor. Faktor pertama adalah pupuk kandang dengan tiga jenis perlakuan, yakni:

P1 : Pupuk kandang ayam

P2 : Pupuk kandang kambing

P3 : Pupuk kandang sapi

Faktor kedua adalah dosis pupuk kandang yang terdiri atas tiga jenis perlakuan, yakni:
D1 : Dosis $10 \mathrm{t} \mathrm{ha}^{-1}\left(3,6 \mathrm{~kg}_{\text {petak }}{ }^{-1}\right)$
D2 : Dosis $20 \mathrm{t} \mathrm{ha}^{-1}\left(7,2 \mathrm{~kg} \mathrm{petak}^{-1}\right)$
D3 : Dosis $30 \mathrm{t} \mathrm{ha}^{-1}\left(10,8 \mathrm{~kg} \mathrm{petak}^{-1}\right)$

Faktor perlakuan di atas dikombinasikan dalam setiap petak percobaan.Percobaan terdiri atas $3 \times$ $3=9$ kombinasi perlakuan dan setiap perlakuan diulang sebanyak tigakali, sehingga terdapat 27 unit percobaan.

Periapan lahan diawali pengolahan tanah pertama, yakni membajak tanah menggunakan hand traktor sampai kedalaman $\pm 30 \quad \mathrm{~cm}$. Selanjutnya dibersihkan dari rumput dan sisa-sisa tanaman sebelumnya yang dianggap dapat menghambat pertumbuhan tanaman.Pengolahan
e-ISSN : 2621-7236

p-ISSN : 1858-134X

tanah kedua dilakukan tujuh hari setelah pengolahan tanah pertama. Pembuatan bedengan untuk petak percobaan dilakukan tujuh hari setelah pengolahan tanah kedua. Bedengan berukuran panjang $300 \mathrm{~cm}$, lebar $120 \mathrm{~cm}$, dan tinggi $\pm 20 \mathrm{~cm}$ sebanyak 27 petak.Lebar parit antar bedengan dalam kelompok $30 \mathrm{~cm}$ dan lebar parit antar kelompok $40 \mathrm{~cm}$.

Pemupukan dilakukan tujuh hari setelah pembuatan bedengan atau tujuh hari sebelum tanam. Dosis pupuk yang digunakan sesuai dengan perlakuan yang dicobakan, yakni dosis 10 $\mathrm{t} \mathrm{ha}^{-1}\left(3,6 \mathrm{~kg}\right.$ petak $\left.^{-1}\right)$, dosis $20 \mathrm{t} \mathrm{ha}^{-1}(7,2 \mathrm{~kg}$ petak $\left.^{-1}\right)$, dan dosis $30 \mathrm{t} \mathrm{ha}^{-1}\left(10,8 \mathrm{~kg}\right.$ petak $\left.^{-1}\right)$. Pemberian pupuk kandang dilakukan dengan cara disebar merata pada seluruh permukaan petak percobaan, selanjutnya dicampurkan kembali dengan tanah.

Penanaman dilakukan tujuh hari setelah pemberian pupuk kandang.Benih ditanam dalam lubang yang dibuat secara tugal sedalam $\pm 2 \mathrm{~cm}$ dengan jarak tanam $20 \mathrm{~cm} \times 15 \mathrm{~cm}$ (120 tanaman petak $\left.^{-1}\right)$.Setiap lubang ditanami dengan 1 benih.Pemeliharaan tanaman meliputi penyulaman, penyiraman, penyiangan, pengendalian hama dan penyakit.Penyulaman dilakukan untuk mengganti benih yang tumbuh tidak normal atau mati.Penyulaman dilakukan satu minggu setelah penanaman.Penyiraman diberikan setiap 3 hari sekali atau berdasarkan kondisi media tumbuh. Penyiraman dilakukan menggunakan gembor dengan jumlah air yang sama untuk setiap petak percobaan. Penyiangan dilakukan setiap satu minggu sekali, dengan cara mencabut atau menggunakan kored. Pengendalian hama dan penyakit dilakukan secara preventif menggunakan pestisida nabati.

Bawang merah varietas Lembah Palu dipanen pada umur 65 hari setelah tanam, yaitu dengan ciri-ciri antara lain80 \% batang melemas, pangkal daun menipis, daun telah menguning dan kering. Panen dilakukan dengan mencabut seluruh tanaman secara hati-hati.

Pengamatan dilakukan terhadap komponen pertumbuhan dan hasil sebagai berikut. Jumlah daun dan tinggi tanaman diamati pada umur 15, 25 dan 35 HST. Volume akar, luas daun, berat segar akar, berat segar daun,berat kering akar dan berat kering daundiamati pada umur 40 HST. Jumlah umbi per rumpun, berat segar umbi danberat segar umbi per petak dan berat segar umbi per hektar, diamati pada saat panen umur 65 HST. 


\section{Jurnal Agrotech 8 (2) 40-49}

\section{Hasil dan Pembahasan}

Jumlah daun (helai)Hasil sidik ragam menunjukkan bahwa faktor jenis pupuk kandang berpengaruh nyata terhadap jumlah daunpada umur $35 \mathrm{HST}$, faktor dosis pupuk kandang dan interaksi keduanya memberikan pengaruh yang tidak nyata terhadap jumlah daun pada umur 15 , 25 dan 35 HST.

Tabel 1.Rata-rata jumlah daun (helai)tanaman umur 15,25 dan 35 HST

\begin{tabular}{lcccc}
\hline \multicolumn{5}{c}{ Umur 15 HST } \\
\hline $\begin{array}{l}\text { Pengaruh } \\
\text { dosis }\end{array}$ & Pengaruh jenis pupuk (P) & Pengaruh \\
\cline { 2 - 5 } pupuk (D) & Ayam & Kambing & Sapi & D \\
\hline $10 \mathrm{t} \mathrm{ha}^{-1}$ & 7,92 & 8,67 & 9,05 & 8,55 \\
$20 \mathrm{t} \mathrm{ha}^{-1}$ & 7,85 & 8,73 & 7,93 & 8,17 \\
$30 \mathrm{t} \mathrm{ha}^{-1}$ & 7,93 & 8,92 & 7,75 & 8,20 \\
\hline Pengaruh P $^{7}$ & 7,90 & 8,77 & 8,24 \\
\hline \multicolumn{5}{c}{ Umur 25 HST } \\
\hline
\end{tabular}

\begin{tabular}{llll}
\hline Pengaruh & \multicolumn{2}{c}{ Pengaruh jenis pupuk (P) } & Pengaruh \\
\cline { 2 - 3 } dosis & Ayam & Kambing & Sapi
\end{tabular}

\begin{tabular}{lllll} 
pupuk (D) & & & D \\
\hline $10 \mathrm{t} \mathrm{ha}^{-1}$ & 12,13 & 13,53 & 13,67 & 13,11 \\
$20 \mathrm{t} \mathrm{ha}^{-1}$ & 12,67 & 14,00 & 12,93 & 13,20 \\
$30 \mathrm{t} \mathrm{ha}^{-1}$ & 13,47 & 15,53 & 12,27 & 13,76 \\
\hline PengaruhP & 12,76 & 14,35 & 12,96 \\
\hline \multicolumn{5}{c}{ Umur 35 HST }
\end{tabular}

\begin{tabular}{lll}
\hline Pengaruh & \multicolumn{3}{c}{ Pengaruh jenis pupuk (P) } & Pengaruh \\
\cline { 2 - 3 } dosis & Ayam Kambing Sapi
\end{tabular}

\begin{tabular}{llllc} 
pupuk (D) & & & & D \\
\hline $10 \mathrm{tha}^{-1}$ & 13,80 & 16,60 & 16,67 & 15,69 \\
$20 \mathrm{t} \mathrm{ha}^{-1}$ & 14,27 & 16,13 & 13,33 & 14,58 \\
$30 \mathrm{t} \mathrm{ha}^{-1}$ & 14,33 & 17,67 & 15,00 & 15,67
\end{tabular}

\section{Pengaruh $\mathrm{P}$}

BNJ $\alpha 0,05 \quad 14,13 b \quad 16,80 a \quad 15,00 a b$

$$
=2,21
$$

Keterangan : Angka yang diikuti oleh huruf yang sama pada kolom yang sama berarti berbeda tidak nyata pada taraf uji BNJ $\alpha$ $=0,05$

Hasil uji BNJ $\alpha$ 0,05 (Tabel 1) menunjukan bahwa perlakuan pupuk kandang kambing menghasilkan pertumbuhan jumlah daun tanaman bawang merah varietas Lembah Palu terbanyak pada umur 35 HST yakni rata-rata 16,80 helai per tanaman, meskipun berbeda tidak nyata dengan pupuk kandang sapi tetapi berbeda nyata dengan pupuk kandang ayam. Sementara perlakuan pupuk kandang sapi berbeda tidak nyata dengan pupuk kandang ayam.

Tinggi tanaman (cm)Hasil sidik ragam menunjukkan bahwa faktor jenis pupuk kandang berpengaruh nyata terhadap tinggi tanaman pada
e-ISSN : 2621-7236

p-ISSN : 1858-134X

umur 25 HST dan faktor dosis pupuk kandang berpengaruh nyata pada umur 25 dan 35 HST, sementara interaksi keduanya berpengaruh nyata pada umur 35 HST.

Tabel 2.Rata-rata tinggi tanaman $(\mathrm{cm})$ umur 15 , 25 dan 35 HST

$$
\text { Umur } 15 \text { HST }
$$

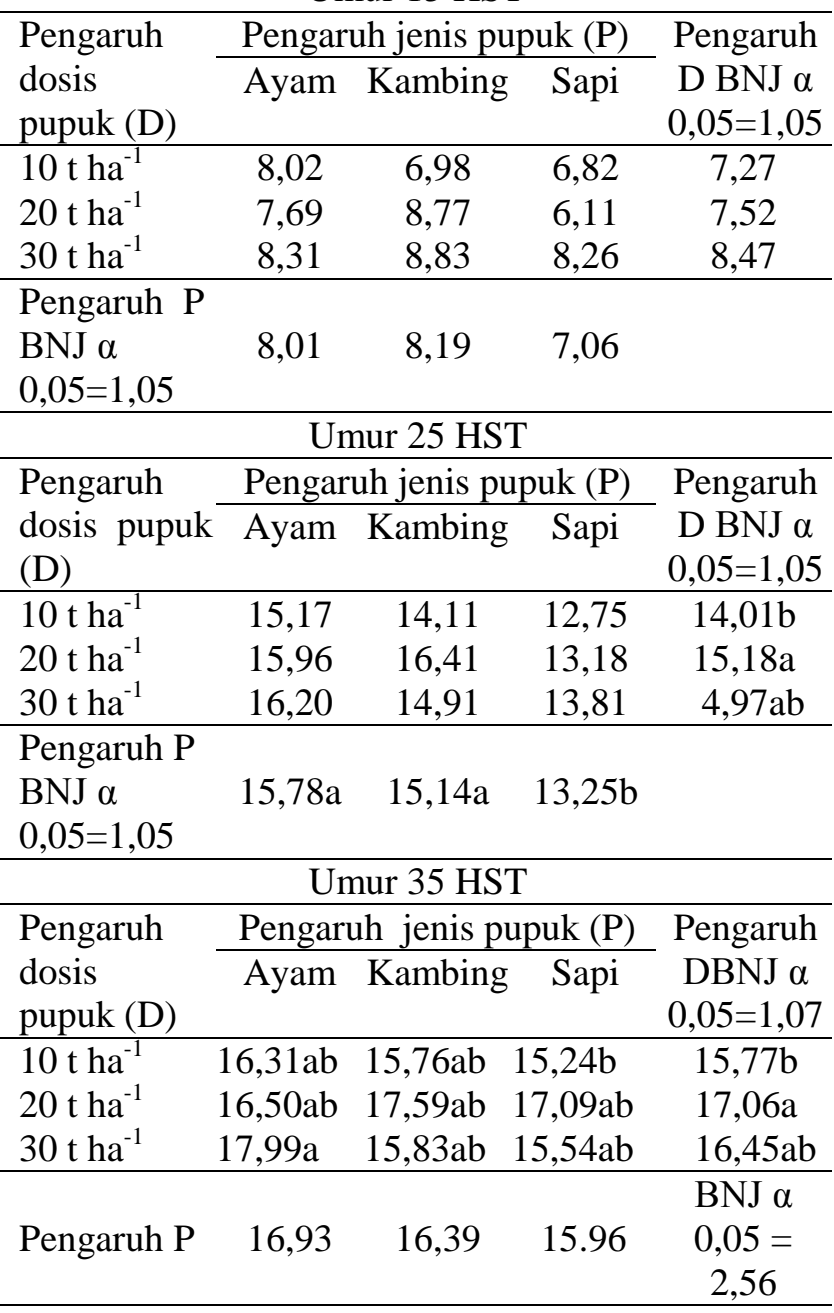

Keterangan : Angka yang diikuti oleh huruf yang sama pada kolom yang sama berarti berbeda tidak nyata pada taraf uji BNJ $\alpha=0,05$

Hasil uji BNJ $\alpha$ 0,05 (Tabel 2) menunjukan bahwa perlakuan pupuk kandang ayam dengan dosis $30 \mathrm{t} \mathrm{ha}^{-1}$ menghasilkan pertumbuhan tinggi tanaman bawang merah varietas Lembah Palu tertinggi pada umur 35 HST yakni rata-rata 17,99 $\mathrm{cm}$, meskipun berbeda tidak nyata dengan perlakuan lainnya kecuali perlakuan pupuk kandang sapi dosis $10 \mathrm{t} \mathrm{ha}^{-1}$ yang menghasilkan tinggi tanaman paling rendah.

Volume akar (ml)Hasil sidik ragam menunjukkan bahwa faktor jenis dan dosis pupuk kandang serta interaksi keduanya berpengaruh tidak nyata terhadap volume akar tanaman 
Jurnal agrotech 8 (2) 40-49

bawang merah varietas Lembah Palu umur 40 HST.

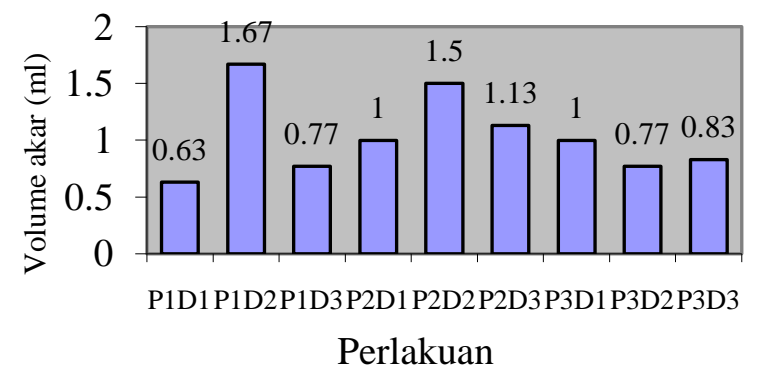

Gambar 1. Rata-rata volume akar tanaman bawang merah variteas Lembah Palu umur 40 HST

Hasil penelitian (Gambar 1) menunjukan bahwa perlakuan pupuk kandang ayam dosis $20 \mathrm{t}$ $\mathrm{ha}^{-1}$ menghasilkan volume akar tanaman bawang merah varietas Lembah Palu cenderung lebih tinggi.

Luas daun $\left(\mathbf{c m}^{2}\right)$ Hasil sidik ragam menunjukkan bahwa faktor jenis pupuk kandang berpengaruh tidak nyata terhadap luas daunpada umur 40 HST,namun faktor dosis pupuk kandang berpengaruh nyata.Sementara itu, interaksi keduanya berpengaruh tidak nyata terhadap luas daun pada umur 40 HST.

Tabel 3.Rata-rata luas daun $\left(\mathrm{cm}^{2}\right)$ umur 40 HST

\begin{tabular}{|c|c|c|c|}
\hline \multirow{2}{*}{$\begin{array}{l}\text { Pengaruh } \\
\text { dosis } \\
\text { pupuk (D) }\end{array}$} & \multicolumn{2}{|c|}{$\begin{array}{c}\text { Pengaruh jenis pupuk } \\
(\mathrm{P})\end{array}$} & \multirow{2}{*}{$\begin{array}{c}\text { Pengaruh D } \\
\text { BNJ } \alpha \\
0,05=22,81\end{array}$} \\
\hline & Ayam & Kambing Sapi & \\
\hline $10 \mathrm{tha}^{-1}$ & 87,74 & 94,25 & $87,65 b$ \\
\hline $20 \mathrm{tha}^{-1}$ & 101,49 & $117,06 \quad 105,79$ & $108,11 \mathrm{ab}$ \\
\hline $30 \mathrm{t} \mathrm{ha}^{-1}$ & 116,15 & $116,10 \quad 111,46$ & $114,57 \mathrm{a}$ \\
\hline $\begin{array}{l}\text { Pengaruh } \\
\text { P }\end{array}$ & 101,79 & $104,71 \quad 103,83$ & \\
\hline Keterangan & $\begin{array}{l}\text { Angl } \\
\text { sama } \\
\text { berbe } \\
=0,05\end{array}$ & ng diikuti oleh & $\begin{array}{l}\text { huruf yang } \\
\text { ma berarti } \\
\text { f uji BNJ } \alpha\end{array}$ \\
\hline
\end{tabular}

Hasil uji BNJ $\alpha$ 0,05 (Tabel 3) menunjukan bahwa perlakuan dosis pupuk kandang $30 \mathrm{t} \mathrm{ha}^{-1}$ menghasilkan luas daun tanaman bawang merah varietas Lembah Palu terbesar yakni rata-rata $114,57 \mathrm{~cm}^{2}$, meskipun berbeda tidak nyata dengan dosis $20 \mathrm{t} \mathrm{ha}^{-1}$ tetapi berbeda nyata dengan dosis $10 \mathrm{t} \mathrm{ha}^{-1}$. Sementara itu, perlakuan dosis $20 \mathrm{t} \mathrm{ha}^{-1}$ berbeda tidak nyata dengan dosis $10 \mathrm{tha}^{-1}$.

Berat segar akar (g) Hasil sidik ragam menunjukkan bahwa faktor jenis dan dosis pupuk kandang,serta interaksi keduanya berpengaruh tidak nyata terhadap berat segar akar pada umur 40 HST.
e-ISSN : 2621-7236

p-ISSN : 1858-134X

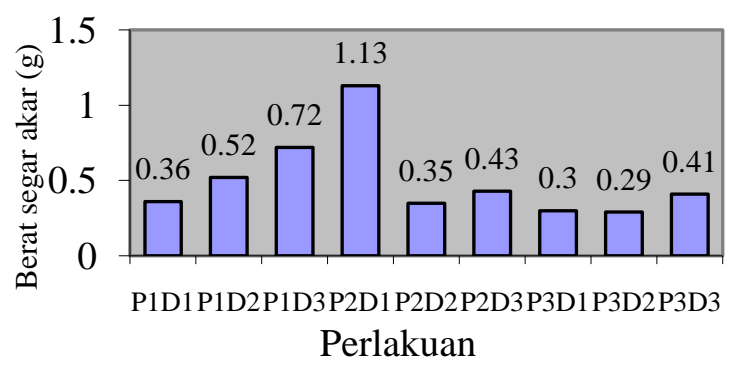

Gambar 2. Rata-rata berat segar akar tanaman bawang merah variteas Lembah Palu umur 40 HST

Hasil penelitian (Gambar 2) menunjukan bahwa perlakuan pupuk kandang kambing dengan dosis $10 \mathrm{t} \mathrm{ha}^{-1}$ menghasilkan berat segar akar tanaman bawang merah varietas Lembah Palu cenderung lebih tinggi.

Berat segar daun (g) Hasil sidik ragam menunjukkan bahwa faktor jenis dan dosis pupuk kandang berpengaruh nyata terhadap berat segar daun, namun interaksi keduanya berpengaruh tidak nyata terhadap berat segar daun pada umur 40 HST.

Tabel 4. Rata-rata berat segar daun (g) umur 40 HST

\begin{tabular}{|c|c|c|c|c|}
\hline \multirow{2}{*}{$\begin{array}{l}\text { Pengaruh } \\
\text { dosis } \\
\text { pupuk (D) }\end{array}$} & \multicolumn{3}{|c|}{$\begin{array}{l}\text { Pengaruh jenis pupuk } \\
(\mathrm{P})\end{array}$} & \multirow{2}{*}{$\begin{array}{c}\text { Pengaruh D } \\
\text { BNJ } \alpha 0,05 \\
\quad=0,80\end{array}$} \\
\hline & Ayam & Kambing & Sapi & \\
\hline $10 \mathrm{tha}^{-1}$ & 8,11 & 6,76 & 6,85 & $7,24 b$ \\
\hline $20 \mathrm{tha}^{-1}$ & 8,60 & 7,90 & 6,98 & $7,83 b$ \\
\hline $30 \mathrm{tha}^{-1}$ & 10,75 & 8,52 & 8,13 & $9,13 \mathrm{a}$ \\
\hline $\begin{array}{l}\text { Pengaruh P } \\
\text { BNJ } \alpha 0,05 \\
=0,80\end{array}$ & $9,16 \mathrm{a}$ & $7,73 b$ & $7,32 b$ & \\
\hline Keterangan & $\begin{array}{l}\text { Angka } \\
\text { sama } p \\
\text { berbeda } \\
=0,05\end{array}$ & g dii & lek & $\begin{array}{l}\text { Iruf yang } \\
\text { a berarti } \\
\text { uji BNJ } \alpha\end{array}$ \\
\hline
\end{tabular}

Hasil uji BNJ $\alpha$ 0,05 (Tabel 4) menunjukan bahwa perlakuan jenis pupuk kandang ayam menghasilkan berat segar daun tanaman bawang merah varietas Lembah Palu tertinggi yakni ratarata $9,16 \mathrm{~g}$ per tanaman dan berbeda nyata dengan jenis pupuk kandang lainnya, sementara perlakuan jenis pupuk kandang kambing berbeda tidak nyata dengan pupuk kandang sapi. Selanjutnya, perlakuan dosis pupuk kandang $30 \mathrm{t}$ $\mathrm{ha}^{-1}$ menghasilkan berat segar daun tanaman bawang merah varietas Lembah Palu tertinggi yakni rata-rata $9,13 \mathrm{~g}$ per tanaman dan berbeda nyata dengan dosis pupuk lainnya, sementara dosis pupuk kandang $20 \mathrm{t} \mathrm{ha}^{-1}$ berbeda tidak nyata dengan dosis $10 \mathrm{tha}^{-1}$. 


\section{Jurnal Ogrotech 8 (2) 40-49}

Berat kering akar (g) Hasil sidik ragam menunjukkan bahwa faktor jenis pupuk kandang berpengaruh nyata terhadap berat kering akar pada umur 40 HST, sementara faktor dosis pupuk kandang dan interaksi keduanya berpengaruh tidak nyata terhadap berat kering akar pada umur 40 HST.

Tabel 5.Rata-rata berat kering akar (g) umur 40 HST

\begin{tabular}{|c|c|c|c|c|}
\hline \multirow{2}{*}{$\begin{array}{l}\text { Pengaruh } \\
\text { dosis } \\
\text { pupuk (D) }\end{array}$} & \multicolumn{3}{|c|}{$\begin{array}{l}\text { Pengaruh jenis pupuk } \\
(\mathrm{P})\end{array}$} & \multirow{2}{*}{$\begin{array}{l}\text { Pengaruh } \\
\text { D }\end{array}$} \\
\hline & Ayam & Kambing & Sapi & \\
\hline $10 \mathrm{t} \mathrm{ha}^{-1}$ & 0,11 & 0,08 & 0,09 & 0,09 \\
\hline $20 \mathrm{tha}^{-1}$ & 0,13 & 0,07 & 0,09 & 0,10 \\
\hline $30 \mathrm{tha}^{-1}$ & 0,14 & 0,08 & 0,07 & 0,10 \\
\hline $\begin{array}{l}\text { Pengaruh P } \\
\text { BNJ } \alpha 0,05 \\
=0,03\end{array}$ & $0,13 \mathrm{a}$ & $0,08 \mathrm{~b}$ & & \\
\hline
\end{tabular}

Keterangan : Angka yang diikuti oleh huruf yang sama pada kolom yang sama berarti berbeda tidak nyata pada taraf uji $\mathrm{BNJ} \alpha$ $=0,05$

Hasil uji BNJ $\alpha$ 0,05 (Tabel 5) menunjukan bahwa perlakuan jenis pupuk kandang ayam menghasilkan berat kering akar tanaman bawang merah varietas Lembah Palu tertinggi yakni ratarata $0,13 \mathrm{~g}$ per tanaman dan berbeda nyata dengan jenis pupuk kandang lainnya, sementara perlakuan jenis pupuk kandang kambing berbeda tidak nyata dengan pupuk kandang sapi.

Berat kering daun (g) Hasil sidik ragam menunjukkan bahwa faktor jenis dan dosis pupuk kandang berpengaruh nyata terhadap berat kering daun pada umur $40 \mathrm{HST}$, sementara interaksi keduanya berpengaruh tidak nyata terhadap berat kering daun pada umur 40 HST.

Tabel 6.Rata-rata berat kering daun (g) umur 40 HST

\begin{tabular}{lcccc}
\hline $\begin{array}{l}\text { Pengaruh } \\
\text { dosis }\end{array}$ & \multicolumn{3}{c}{$\begin{array}{c}\text { Pengaruh jenis pupuk } \\
(\mathrm{P})\end{array}$} & $\begin{array}{c}\text { Pengaruh D } \\
\text { BNJ } \alpha 0,05 \\
\text { pupuk (D) }\end{array}$ \\
\cline { 2 - 4 } & Ayam & Kambing & Sapi & 0,22 \\
\hline $10 \mathrm{t} \mathrm{ha}^{-1}$ & 1,34 & 1,24 & 1,18 & $1,25 \mathrm{~b}$ \\
$20 \mathrm{t} \mathrm{ha}^{-1}$ & 1,41 & 1,29 & 1,21 & $1,30 \mathrm{~b}$ \\
$30 \mathrm{t} \mathrm{ha}^{-1}$ & 1,99 & 1,35 & 1,48 & $1,61 \mathrm{a}$ \\
\hline $\begin{array}{l}\text { Pengaruh P } \\
\text { BNJ } \alpha 0,05\end{array}$ & $1,58 \mathrm{a}$ & $1,29 \mathrm{~b}$ & $1,29 \mathrm{~b}$ & \\
$=0,22$ & & & & \\
\hline
\end{tabular}

Keterangan : Angka yang diikuti oleh huruf yang sama pada kolom yang sama berarti berbeda tidak nyata pada taraf uji BNJ $\alpha$ $=0,05$

Hasil uji BNJ $\alpha$ 0,05 (Tabel 6) menunjukan bahwa perlakuan jenis pupuk kandang ayam menghasilkan berat kering daun tanaman bawang merah varietas Lembah Palu tertinggi yakni ratarata $1,58 \mathrm{~g}$ per tanaman dan berbeda nyata
e-ISSN : 2621-7236

p-ISSN : 1858-134X

dengan jenis pupuk kandang lainnya, sementara perlakuan jenis pupuk kandang kambing berbeda tidak nyata dengan pupuk kandang sapi. Selanjutnya, perlakuan dosis pupuk kandang $30 \mathrm{t}$ $\mathrm{ha}^{-1}$ menghasilkan berat kering daun tanaman bawang merah varietas Lembah Palu tertinggi yakni rata-rata 1,61 g per tanaman dan berbeda nyata dengan dosis pupuk kandang lainnya, sementara dosis pupuk kandang $20 \mathrm{t} \mathrm{ha}^{-1}$ berbeda tidak nyata dengan dosis $10 \mathrm{tha}^{-1}$.

Jumlah umbi per rumpun (buah) Hasil sidik ragam menunjukkan bahwa faktor jenis pupuk kandang berpengaruh nyata terhadap jumlah umbi per rumpun saat panen, sementara faktor dosis pupuk kandang dan interaksi keduanya berpengaruh tidak nyata terhadap jumlah umbi per rumpun saat panen.

Tabel 7.Rata-rata jumah umbi per rumpun (buah) saat panen

\begin{tabular}{lcccc}
\hline $\begin{array}{l}\text { Pengaruh } \\
\text { dosis } \\
\text { (D) }\end{array}$ & \multicolumn{2}{c}{$\begin{array}{c}\text { Pengaruh jenis pupuk } \\
(\mathrm{P})\end{array}$} & $\begin{array}{c}\text { Pengaruh } \\
\text { D }\end{array}$ \\
\cline { 2 - 3 } & Ayam & Kambing Sapi & \\
\hline $10 \mathrm{t} \mathrm{ha}^{-1}$ & 4,80 & 5,33 & 5,80 & 5,31 \\
$20 \mathrm{t} \mathrm{ha}^{-1}$ & 4,87 & 6,07 & 5,53 & 5,49 \\
$30 \mathrm{t} \mathrm{ha}^{-1}$ & 4,93 & 5,27 & 4,80 & 5,00 \\
\hline Pengaruh P & & & \\
BNJ $\alpha 0,05=$ & $4,87 \mathrm{~b}$ & $5,56 \mathrm{a}$ & $5,38 \mathrm{ab}$ \\
0,64 & & & \\
\hline Keterangan : & Angka yang diikuti oleh huruf yang \\
& sama pada kolom yang sama berarti \\
& berbeda tidak nyata pada taraf uji BNJ $\alpha$ \\
& $=0,05$
\end{tabular}

Hasil uji BNJ $\alpha$ 0,05 (Tabel 7) menunjukan bahwa perlakuan jenis pupuk kandang kambing menghasilkan jumlah umbi per rumpun tanaman bawang merah varietas Lembah Palu terbanyak yakni rata-rata 5,56 buah per rumpun, meskipun berbeda tidak nyata dengan pupuk kandang sapi tetapi berbeda nyata dengan pupuk kandang ayam. Namun, perlakuan jenis pupuk kandang sapi berbeda tidak nyata dengan pupuk kandang ayam.

Berat segar umbi per rumpun (g) Hasil sidik ragam menunjukkan bahwa faktor jenis pupuk kandang berpengaruh nyata terhadap berat segar umbi per rumpun saat panen, sementara faktor dosis pupuk kandang dan interaksi keduanya berpengaruh tidak nyata terhadap berat segar umbi per rumpun saat panen. 


\section{Jurnal agrotech 8 (2) 40-49}

Tabel 8.Rata-rata berat segar umbi per rumpun (g) saat panen

\begin{tabular}{lcccc}
\multicolumn{3}{c}{ panen } \\
\hline $\begin{array}{l}\text { Pengaruh } \\
\text { dosis }\end{array}$ & \multicolumn{2}{c}{$\begin{array}{c}\text { Pengaruh jenis pupuk } \\
(\mathrm{P})\end{array}$} & $\begin{array}{c}\text { Pengaruh } \\
\text { pupuk }\end{array}$ & \multicolumn{3}{c}{ Ayam Kambing Sapi } & D \\
\cline { 2 - 4 }$(\mathrm{D})$ & & & & \\
\hline $10 \mathrm{t} \mathrm{ha}^{-1}$ & 16,46 & 16,29 & 16,23 & 16,33 \\
$20 \mathrm{t} \mathrm{ha}^{-1}$ & 17,02 & 16,73 & 15,83 & 16,53 \\
$30 \mathrm{t} \mathrm{ha}^{-1}$ & 18,14 & 16,23 & 15,76 & 16,71 \\
\hline
\end{tabular}

Pengaruh $\mathrm{P}$

BNJ $\alpha 0,05 \quad 17,21 \mathrm{a} \quad 16,41 \mathrm{ab} \quad 15,94 \mathrm{~b}$ $=0,95$

Keterangan : Angka yang diikuti oleh huruf yang sama pada kolom yang sama berarti berbeda tidak nyata pada taraf uji BNJ $\alpha$ $=0,05$

Hasil uji BNJ $\alpha$ 0,05 (Tabel 8) menunjukan bahwa perlakuan jenis pupuk kandang ayam menghasilkan berat segar umbi per rumpun tanaman bawang merah varietas Lembah Palu tertinggi yakni rata-rata $17,21 \mathrm{~g}$ per rumpun, meskipun berbeda tidak nyata dengan pupuk kandang kambing tetapi berbeda nyata dengan pupuk kandang sapi. Namun, perlakuan jenis pupuk kandang kambing berbeda tidak nyata dengan pupuk kandang sapi.

Berat segar umbi per petak (kg) Hasil sidik ragam menunjukkan bahwa faktor dosis pupuk kandang berpengaruh nyata terhadap berat segar umbi per petak pada saat panen, sementara faktor jenis pupuk kandang dan interaksi keduanya berpengaruh tidak nyata terhadap berat segar umbi per petak pada saat panen.

Tabel 9. Rata-rata berat segar umbi per petak $(\mathrm{kg})$ saat panen

\begin{tabular}{|c|c|c|c|c|}
\hline \multirow{2}{*}{$\begin{array}{l}\text { Pengaruh } \\
\text { dosis } \\
\text { pupuk (D) }\end{array}$} & \multicolumn{3}{|c|}{$\begin{array}{l}\text { Pengaruh jenis pupuk } \\
\text { (P) }\end{array}$} & \multirow{2}{*}{$\begin{array}{l}\text { Pengaruh D } \\
\text { BNJ } \alpha \\
0,05=0,02\end{array}$} \\
\hline & $\overline{\text { Ayam }}$ & Kambin & Sapi & \\
\hline $10 \mathrm{tha}^{-1}$ & 0,40 & 0,40 & 0,40 & $0,40 \mathrm{~b}$ \\
\hline $20 \mathrm{t}$ & 0,41 & 0,42 & 0,40 & $a b$ \\
\hline $30 \mathrm{t}$ & 0,45 & 0,41 & 0,44 & \\
\hline Pengaruh $\mathrm{P}$ & 0,42 & 0,41 & 0,41 & \\
\hline 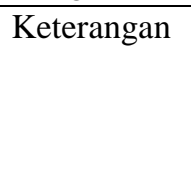 & $n$ & & & \\
\hline
\end{tabular}

Hasil uji BNJ $\alpha$ 0,05 (Tabel 9) menunjukan bahwa perlakuan dosis pupuk kandang $30 \mathrm{t} \mathrm{ha}^{-1}$ menghasilkan berat segar umbi per petak tanaman bawang merah varietas Lembah Palu tertinggi yakni rata-rata $0,43 \mathrm{~kg}$ petak $^{-1}$, meskipun berbeda tidak nyata dengan dosis $20 \mathrm{t}$ $\mathrm{ha}^{-1}$ tetapi berbeda nyata dengan dosis $10 \mathrm{t} \mathrm{ha}^{-1}$.
e-ISSN : 2621-7236

p-ISSN : 1858-134X

Namun, perlakuan dosis pupuk kandang dosis 20 $\mathrm{t} \mathrm{ha} \mathrm{e}^{-1}$ berbeda tidak nyata dengan dosis $10 \mathrm{t} \mathrm{ha}^{-1}$.

Berat segar umbi per hektar (t) Hasil sidik ragam menunjukkan bahwa faktor dosis pupuk kandang berpengaruh nyata terhadap berat segar umbi per petak pada saat panen, sementara faktor jenis pupuk kandang dan interaksi keduanya berpengaruh tidak nyata terhadap berat segar umbi per petak pada saat panen.

Tabel 10. Rata-rata berat segar umbi per hektar ( $t$ ) saat panen

\begin{tabular}{|c|c|c|c|c|}
\hline \multirow{2}{*}{$\begin{array}{l}\text { Pengaruh } \\
\text { dosis pupuk } \\
\text { (D) }\end{array}$} & \multicolumn{3}{|c|}{$\begin{array}{l}\text { Pengaruh jenis pupuk } \\
(\mathrm{P})\end{array}$} & \multirow{2}{*}{$\begin{array}{c}\text { Pengaruh } \\
\text { DBNJ } \alpha \\
0,05=0,24\end{array}$} \\
\hline & Ayam & Kambing & Sapi & \\
\hline $10 \mathrm{tha}^{-1}$ & 4,02 & 4,04 & 4,04 & $4,03 \mathrm{~b}$ \\
\hline $20 \mathrm{tha}^{-1}$ & 4,09 & 4,16 & 4,01 & $4,09 \mathrm{ab}$ \\
\hline $30 \mathrm{tha}^{-1}$ & 4,49 & 4,07 & 4,37 & $4,31 \mathrm{a}$ \\
\hline Pengaruh P & 4,20 & 4,09 & 4,14 & \\
\hline Keterangan & $\begin{array}{l}\text { Angka } \\
\text { sama } \\
\text { berbed } \\
=0,05\end{array}$ & g diikt & oleh & $\begin{array}{l}\text { ruf yang } \\
\text { la berarti } \\
\text { uii BNJ } \alpha\end{array}$ \\
\hline
\end{tabular}

Hasil uji BNJ $\alpha$ 0,05 (Tabel 10) menunjukan bahwa perlakuan dosis pupuk kandang $30 \mathrm{t} \mathrm{ha}^{-1}$ menghasilkan berat segar umbi per hektar tanaman bawang merah varietas Lembah Palu tertinggi yakni rata-rata 4,31 $\mathrm{tha}^{-1}$, meskipun berbeda tidak nyata dengan dosis $20 \mathrm{t}$ $\mathrm{ha}^{-1}$ tetapi berbeda nyata dengan dosis $10 \mathrm{t} \mathrm{ha}^{-1}$. Namun, perlakuan dosis pupuk kandang dosis 20 $\mathrm{t} \mathrm{ha}{ }^{-1}$ berbeda tidak nyata dengan dosis $10 \mathrm{tha}^{-1}$.

\section{Pembahasan}

Hasil penelitian menunjukkan bahwa perlakuan tunggal jenis pupuk kandang berpengaruh nyata terhadap jumlah daun, tinggi tanaman, berat segar daun, berat kering akar, berat kering daun, jumlah umbi per rumpun dan berat segar umbi per rumpun. Perlakuan tunggal dosis pupuk kandang berpengaruh nyata terhadap tinggi tanaman, luas daun, berat segar daun, berat kering daun, berat segar umbi per petak, dan berat segar umbi per hektar. Kombinasi antara kedua perlakuan berinteraksi pada parameter tinggi tanaman umur 35 HST.

Perlakuan jenis pupuk kandang secara tunggal memberikan pengaruh nyata terhadap pertumbuhan dan hasil tanaman bawang merah varietas Lembah Palu. Hal ini menunjukkan bahwa perbedaan jenis pupuk kandang akan memperlihatkan respons tanaman yang berbeda pula. Pupuk kandang ayam memberikan pengaruh terbaik terhadap semua parameter, kecuali pada jumlah daun dan jumlah umbi per reumpun yang lebih rendah. Namun jika dilihat 


\section{Jurnal agrotech 8 (2) 40-49}

pada parameter berat segar daun dan berat segar umbi, perlakuan pupuk kandang ayam justru memberikan hasil yang lebih tinggi. Artinya bahwa meskipun jumlah daunnya lebih sedikit, namun ukurannya rata-rata lebih besar.Demikian pula dengan jumlah umbi yang lebih sedikit, namun ukurannya rata-rata lebih besar.Berdasarkan hal tersebut, dapat disimpulkan bahwa pupuk kandang ayam secara keseluruhan memberikan pengaruh lebih baik terhadap pertumbuhan dan hasil tanaman bawang merah varietas Lembah Palu bila dibandingkan dengan jenis pupuk kandang kambing dan sapi.

Perbedaan susunan komponen unsur hara merupakan salah satu faktor penyebab perbedaan tanggap tanaman terhadap pemberian pupuk kandang.Berdasarkan hasil analisis pupuk kandang yang digunakan bahwa kandungan $\mathrm{N}, \mathrm{P}$, $\mathrm{K}$ dan C-Organik pada pupuk kandang ayam ratarata lebih tinggi dibandingkan dengan pupuk kandang lainnya.Ayam atau unggas pada umumnya yang diberi ransum dari pabrik biasanya mengandung protein dan mineral. Menurut Setyamidjaja (1986) hewan yang diberi ransum yang banyak mengandung protein dan mineral akan menghasilkan kotoran yang memiliki kandungan Nitrogen serta mineral lainnya yang tinggi pula.Hal ini menyebabkan kandungan Nitrogen pada pupuk kandang ayam lebih tinggi apabila dibandingkan dengan pupuk kandang sapi ataupun pupuk kandang kambing.

Lingga (2002) menyatakan bahwa unsur Nitrogen bagi tanaman dapat merangsang pertumbuhan tanaman secara keseluruhan khususnya batang dan daun. Selanjutnya Gardner et al. (1991) menambahkan bahwa secara umum penggunaan Nitrogen pada tanaman mampu menghasilkan pertumbuhan vegetatif yang lebih cepat, meningkatkan panjang batang, memperbesar ukuran daun dan memberikan warna daun lebih hijau. Menurut Prawiranata $d k k$. (1991) pemberian unsur Nitrogen dapat meningkatkan laju fotosintesis tanaman sehingga dapat memacu pertumbuhan vegetatif. Peningkatan jumlah Nitrogen akan menghasilkan protein dalam jumlah banyak pada tanaman, sehingga meningkatkan pertumbuhan jaringan tanaman dan berat tanaman juga meningkat.

Berat kering merupakan bahan organik yang terdapat dalam bentuk biomasa. Berat kering menunjukkan proses penangkapan energi oleh tanaman pada proses fotosintesis. Berdasarkan hasil analisis ragam, dapat diketahui bahwa perlakuan tunggal jenis pupuk kandang
e-ISSN : 2621-7236

p-ISSN : 1858-134X

berpengaruh nyata terhadap berat kering tanaman (akar dan daun), dimana pupuk kandang ayam memberikan pengaruh terbaik.Unsur hara $\mathrm{N}$ pada pupuk kandang ayam diduga berperan penting dalam meningkatkan berat kering tanaman.Buckman and Brady (1982) menyatakan bahwa pada tanaman, Nitrogen berfungsi untuk memperbesar ukuran daun dan meningkatkan prosentase protein. Ukuran daun yang besar dan protein yang banyak akan meningkatkan berat kering tanaman.

Hasil penelitian menunjukkan bahwa perlakuan dosis pupuk kandang secara tunggal berpengaruh nyata terhadap pertumbuhan dan hasil tanaman bawang merah varietas Lembah Palu. Dosis $30 \mathrm{t} \mathrm{ha}^{-1}$ memberikan hasil terbaik terhadap tanaman bawang merah, selanjutnya diikuti dosis $20 \mathrm{t} \mathrm{ha}^{-1}$ dan $10 \mathrm{t} \mathrm{ha}^{-1}$. Hal ini menunjukkan bahwa tingkat pertumbuhan terus meningkat seiring dengan pemberian pupuk kandang dengan dosis yang semakin tinggi, sehingga mencukupi kebutuhan kandungan unsur hara untuk tanaman.Semakin meningkatnya pemberian dosis pupuk kandang maka pertumbuhan tanaman semakin baik pula, sehingga meningkatkan produksinya. Dimana dengan pemberian pupuk kandang dengan dosis yang tinggi sampai dengan $30 \mathrm{t} \mathrm{ha}^{-1}$, akan meningkatkan pertumbuhanbawang merah dan proses fisiologis dalam jaringan tanaman pun akan berjalan dengan baik, sehingga hasil fotosintesa yang ditranslokasikan kedalam umbi juga semakin tinggi. Hal demikian menunjukkan bahwa kandungan unsur hara seperti N, P, dan K yang terdapat pada pupuk kandang dapat dimanfaatkan oleh tanaman secara optimal.

Nyakpa dkk. (1998) yang menyatakan bahwa untuk membentuk jaringan tanaman dibutuhkan unsur hara, dengan adanya unsur hara yang seimbang akan menambah berat tanaman. Selanjutnya Umboh dan Andre (1997) menambahkan bahwa penyerapan unsur hara yang tinggi menyebabkan proses fotosintesa juga akan tinggi pula dan hal ini akan meningkatkan pertumbuhan umbi. Selanjutnya Munawar (2011) menyatakan bahwa pertumbuhan, perkembangan dan hasil suatu tanaman akan meningkat apabila pasokan unsur hara tidak menjadi faktor pembatas.

Kombinasi perlakuan antara jenis dan dosis pupuk kandang menunjukkan interaksi yang nyata pada parameter tinggi tanaman umur 35 HST.Hasil terbaik yang diperoleh adalah kombinasi pupuk kandang ayam dengan dosis 30 


\section{Jurnal agrotech 8 (2) 40-49}

$\mathrm{t} \mathrm{ha}^{-1}$.Semakin tinggi dosis yang diberikan, pertumbuhan tinggi tanaman cenderung semakin tinggi.Hal ini menunjukkan bahwa tanaman bawang merah varietas Lembah Palu lebih efektif menyerapar unsur hara pada pupuk kandang ayam dengan dosis $30 \mathrm{t} \mathrm{ha}^{-1}$.

Peningkatan efisiensi pemupukan dapat dilakukan dengan pemberian bahan organik.Salah satu sumber bahan organik yang banyak tersedia disekitar petani adalah pupuk kandang. Pemberian pupuk kandang dapat mengurangi penggunaan dan meningkatkan efisiensi penggunaan pupuk anorganik juga akan menyumbangkan unsur hara bagi tanaman serta meningkatkan serapan unsur hara oleh tanaman (Wigati $d k k ., 2006$ ).

Pemberian pupuk kandang dapat memperbaiki petumbuhan tanaman karena dapat meningkatkan kadar humus dan unsur hara dalam tanah. Pupuk kandang mempunyai kemampuan untuk merubah semua faktor-faktor kesuburan tanah seperti unsur hara, menaikkan kandungan humus, dan struktur tanah. Dari aspek fisik pupuk kandang mendorong proses penggemburan tanah, sehingga dapat menunjang pertumbuhan dan perkembangan bawang merah. Hasil penguraian senyawa kompleks seperti polisakarida dari pupuk kandang dapat mengikat partikel-partikel tanah kedalam unit-unit agregat yang porous sehingga memudahkan infiltrasi dan perkolasi.Kondisi ini meningkatkan pasokan oksigen untuk respirasi serta pertumbuhan akar karena pertukaran gas menjadi lebih baik (Muhardi, 2002 dalam Latarang dan Syakur, 2006).

Berdasarkan hasil penelitian ini dapat dilihat bahwa respon pertumbuhan tanaman bawang merah varietas Lembah Palu akibat perlakuan jenis dan dosis pupuk kandang yang dicobakan sangat rendah bila dibandingkan dengan potensi genetiknya. Hal ini dapat dilihat dari pengamatan jumlah daun dan tinggi tanaman yang hanya mencapai rata-rata tertinggi masingmasing 17,67 helai/rumpun dan 17,99 $\mathrm{cm}$. Berdasarkan deskripsi bawang merah varietas Lembah Palu bahwa jumlah daun dan tinggi tanaman dapat mencapai 50 - 55 helai/rumpun dan $36-37 \mathrm{~cm}$.

Pertumbuhan tanaman yang rendah pada umumnya akan berimplikasi pada rendahnya produksi. Asumsi tersebut sesuai dengan hasil penelitian ini bahwa komponen hasil tanaman bawang merah varietas Lembah Palu masih jauh dibawah potensi genetiknya. Hasil tertinggi
e-ISSN : 2621-7236

p-ISSN : 1858-134X

jumlah umbi per rumpun, berat umbi per rumpun dan hasil per hektar yang diperoleh masingmasing hanya mencapai rata-rata 6,07 buah/rumpun, 18,14 g/rumpun dan 4,49 ton/ha. Sementara berdasarkan deskripsi bawang merah varietas Lembah Palu bahwa jumlah umbi per rumpun, berat umbi per rumpun dan hasil per hektar masing-masing dapat mencapai 9 - 12 buah/rumpun, 35,1 - 68,4 g/rumpun dan 9,7 ton/ha.

Salah satu faktor yang diduga menyebabkan rendahnya produktivitas bawang merah varietas Lembah Palu pada penelitian ini adalah kondisi media tumbuh lahan percobaan sebelum aplikasi pupuk kandang yang kurang mendukung untuk pertumbuhan dan perkembangan tanaman karena memiliki kandungan/kadar unsur hara rendah, seperti COrganik yang hanya memilki kadar $0,99 \%$. COrganik tanah menggambarkan keadaan bahan organik dalam tanah, sementara tanah yang subur memiliki kandungan C-Organik tidak kurang dari 5\%.Utami dan Handayani (2003) menjelaskan bahwa C-organik tanah dapat mempengaruhi sifat tanah menjadi lebih baik secara fisik, kimia dan biologi. Karbon merupakan sumber makanan mikroorganisme tanah, sehingga keberadaan Corganik dalam tanah akan memacu kegiatan mikroorganisme sehingga meningkatkan proses dekomposisi tanah dan juga reaksi-reaksi yang memerlukan bantuan mikroorganisme, misalnya pelarutan $\mathrm{P}$, dan fiksasi $\mathrm{N}$.

Selain karena kandungan unsur hara pada lahan percobaan yang cukup rendah, faktor lain yang menyebabkan rendahnya produksi adalah ketersediaan unsur hara dari pupuk kandang yang diberikan. Diduga bahwa unsur hara dari pupuk kandang yang digunakan belum cukup tersedia untuk tanaman pada saat fase pertumbuhan dan perkembangannya.Hal ini dijelaskan oleh Sutedjo (2008) bahwa penggunaan pupuk kandang mempunyai kelemahan yaitu penguraiannya lambat sehingga ketersediaannya untuk tanaman lambat pula.

\section{Kesimpulan}

1. Kombinasi perlakuan berbagai jenis dan dosis pupuk kandang ayam berinteraksi pada parameter tinggi tanaman umur 35 HST, dimana perlakuan pupuk kandang ayam dengan dosis $30 \mathrm{t} \mathrm{ha}^{-1}$ memberikan hasil lebih baik.

2. Perlakuan tunggal jenis pupuk kandang ayam memberikan hasil lebih baik terhadap tinggi 


\section{Jurnal Ogrotech 8 (2) 40-49}

tanaman, berat segar daun, berat kering akar, berat kering daun dan berat segar umbi per rumpun.

3. Perlakuan tunggal dosis pupuk kandang $30 \mathrm{t}$ $\mathrm{ha}^{-1}$ memberikan hasil lebih baik terhadap tinggi tanaman, luas daun, berat segar daun, berat kering daun, berat segar umbi per petak, dan berat segar umbi per hektar.

\section{Daftar Pustaka}

BPS, 2015.Luas Panen, Hasil per Hektar dan Produksi Tanaman Sayuran. Badan Pusat Statistik Sulawesi Tengah, Palu.

Buckman, H.O., and N.C. Brady, 1982.The Nature and Properties of Soil. MC Milan Publishing CO, New York. Diterjemahkan oleh Soegiman. Penerbit Bhratara Karya Akasara, Jakarta.

Gardner, F.P., R.B. Pearce, and R.L. Mitchell, 1991.Physiology of Crop Plants.Diterjemahkan oleh Susilo dan Subiyanto. UI Press, Jakarta.

Latarang, B. dan A. Syakur, 2006. Pertumbuhan dan Hasil Bawang Merah (Allium ascalonicum L.) pada Berbagai Dosis Pupuk Kandang. Jurnal Agroland, 3(3): 265-269.

Limbongan dan Maskar, 2003.Potensi Pengembangan dan Ketersediaan Teknologi Bawang Merah Palu di Sulawesi Tengah. Jurnal Litbang Pertanian, 22(3): 103-108.

Lingga, P.M., 2002. Petunjuk Penggunaan Pupuk. Penebar Swadaya, Jakarta.
e-ISSN : 2621-7236

p-ISSN : 1858-134X

Nyakpa, M.Y. Lubis, A.M. Pulung, M.A. Amroh, A.G, Munawar, A. Hong, G.B dan N. Hakim, 1988. Kesuburan Tanah. Universitas Lampung, Bandar Lampung.

Parman, S., 2007.Pengaruh Pemberian Pupuk Organijk Cair TerhadapPertumbuhan dan Produksi Kentang (Solanum tuberosum L.). Buletin Anatomi dan Fisiologi 15(2): 21-31.

Prawiranata W, S. Harran, P. Tjondronegoro, 1991. Dasar-Dasar Fisiologi Tumbuhan. Jurusan Biologi Fakultas MIPA Institut Pertanian Bogor, Bogor.

Setiawan, A.I., 1996. Memanfaatkan Kotoran Ternak. Penebar Swadaya, Jakarta.

Setyamidjaja, D., 1986. Pupuk dan Pemupukan. Penerbit CV Simplek, Jakarta.

Sutedjo, M.M., 2008. Pupuk dan Cara Pemupukan. Rineka Cipta, Jakarta.

Umboh dan Andre, 1997.Petunjuk Penggunaan Mulsa. Penebar Swadaya, Jakarta.

Utami, S. N. H. dan S. Handayani.2003. Sifat Kimia Entisol pada Pertanian Organik. Jurnal Ilmu Pertanian 10: 63-69.

Wigati, E.S., A. Syukur, dan D.K.Bambang, 2006. Pengaruh Takaran Bahan Organik dan Tingkat Kelengasan Tanah Terhadap Serapan Fosfor oleh Kacang Tunggak di Tanah Pasir Pantai. J. Ilmu Tanah Lingk. 6(2): 52-58. 